\title{
Fenomena Pemberitaan Media Indonesia dalam Konflik Senjata Kimia di Ghouta Timur (Berdasarkan Perspektif Edmund Husserl)
}

\author{
Muhammad Naufal Annabil ${ }^{1}$ \\ ${ }^{1}$ Program Studi Bahasa dan Sastra Arab, Magister Universitas Islam Negeri Sunan Kalijaga, \\ Jl. Laksda Adisucipto Papringan, Caturtunggal, Kec. Depok, Kabupaten Sleman, Yogyakarta 55281 \\ Penulis untuk Korespondensi/E-mail: 20201011017@student.uin-suka.ac.id
}

\begin{abstract}
This article aims to describe the chemical weapons conflicts in Ghouta East, Syria based on the perspective of Edmund Husserl. The problems to be studied are the chemical weapons conflict in East Ghouta; the impact of chemical weapons use, and media in Indonesia's view of the chemical weapons conflict in East Ghouta through the line of phenomenology theory of Edmund Husserl. The research method used is the qualitative method. Data collection is used with watching, seeing, reading, and note techniques. The data analysis technique used is the descriptive analysis technique. To examine the validity of data, the technique used is the triangulation technique. As for the result of this research is the armed conflict occurred because of the opposition in East Ghouta and Assad's regime with its soldiers trying to eradicate the opposition; chemical weapons caused many injured victims to die, especially children; a dispute between the Western media and the Indonesian media in the news of the conflict in East Ghouta.
\end{abstract}

Abstrak - Artikel ini bertujuan untuk mendeskripsikan konflik senjata kimia di Ghouta Timur, Suriah berdasarkan perspektif Edmund Husserl. Adapun permasalahan yang akan diteliti, yaitu: konflik senjata kimia di Ghouta Timur; dampak pendayagunaan senjata kimia; dan pandangan Media di Indonesia terkait konflik senjata kimia di Ghouta Timur melalui garis pandang teori fenomenologi Edmund Husserl. Metode penelitian yang digunakan adalah metode kualitatif. Pengumpulan data digunakan dengan teknik tonton, simak, baca dan catat. Teknik analisis data yang digunakan adalah teknik analisis deskriptif. Untuk menguji keabsahan data, teknik yang digunakan adalah teknik triangulasi. Adapun hasil dari penelitian ini adalah konflik senjata terjadi karena adanya para oposisi yang ada di Ghouta Timur dan rezim Assad dengan tentaranya berupaya memberantas para oposisi tersebut; senjata kimia mengakibatkan banyak korban yang terluka dan meninggal, terutama anakanak; adanya perselisihan pandangan antara media Barat dengan media Indonesia dalam pemberitaan tentang konflik di Ghouta Timur.

Keywords - phenomenology, Indonesian media, chemical weapon, East Ghouta, Edmund Husserl

\section{PENDAHULUAN}

$\mathrm{M}$ asalah pendayagunaan senjata kimia di dalam peperangan kembali menjadi sorotan publik Internasional setelah beberapa waktu yang lalu diketahui adanya korban dari pendayagunaan senjata itu dalam perang Irak-Iran. Pendayagunaan senjata kimia dalam perang memang bukan perihal baru dalam abad ini. Sejak lahir abad lalu, masyarakat Internasional sebenarnya sudah menyadari akibat yang mengerikan dalam pendayagunaan senjata kimia [1].

Secara umum pemahaman mengenai senjata kimia dapat dibatasi sebagai sebuah senjata yang isinya mengandung bahan kimia atau senyawa dari beragam unsur dari kimia. Pendayagunaan senjata kimia dapat mengakibatkan kelumpuhan, kerusakan tubuh atau kerusakan syaraf bahkan menyebabkan penyakit yang berdampak hingga bertahun-tahun 
bahkan bisa berdampak sebagai penyebab sebuah kematian. Selain itu dapat menyebabkan kerusakan lingkungan alam, yang sebelumnya asri menjadi tanah tandus. Sejalan dengan hal tersebut, Edmund Husserl memperkenalkan suatu konsep fenomenologi yang berguna untuk mengetahui suatu konflik atau fenomena yang tampak secara knkret atau kasat mata [1].

Selain fenomenologi merupakan bagian dari aliran filsafat, fenomonologi merupakan sebuah metode berpikir yang dipelopori oleh Edmund Husserl, yang beranjak dari kebenaran fenomena, seperti yang terlihat apa adanya. Suatu fenomena yang terlihat sebenarnya merupakan refleksi yang tidak berdiri sendiri, karena yang terlihat itu adalah objek yang penuh dengan makna yang luas, sukar dipahami secara sempurna, dan kompleks [2].

Fenomenologi merupakan sebuah pandangan sosiologi yang sanggup mengundang keprihatinan pada kehidupan sehari-hari selain ethnomethodology, sosiologi eksistensial, dramaturgi, interaksionisme simbolik, teori labeling, dan sosiologi postmodern. Di antara pandangan secara teoretis yang telah disebutkan terdapat sebuah ide utama yang hampir mirip, yaitu dengan mempertahankan tabiat fenomena. Peneliti harus mencurahkan waktu dengan anggota masyarakat yang ditelitinya untuk mendapatkan sebuah pemahaman tentang bagaimana pandangan suatu kelompok dan menjelaskan mengenai dunia kehidupan sosial tempat anggota masyarakat menjalani kehidupan mereka dalam setiap harinya. Peneliti tidak boleh menyertakan asumsi teoretis dalam studi yang dilakukan, akan tetapi harus membentuk sebuah ide yang bersumber dari sekelompok masyarakat [3].

Husserl mengemukakan bahwa ilmu positif harus beriringan dengan sebuah pendekatan, yaitu filsafat fenomenologis. Pemahaman Husserl dimulai dari ajakan kembali pada sumber atau kembali kepada realitas yang sesungguhnya. Untuk itu, diperlukan beberapa langkah metodis yang disebut sebagai "reduksi". Melalui reduksi, artinya menunda sebuah usaha penyimpulan secara serampangan dari setiap prasangka terhadap sebuah realitas. Ragam langkah metodis yang perlu dilalui adalah reduksi eidetis, reduksi fenomenologi, dan reduksi transendental [2].

Sehubungan dengan itu, kajian mengenai fenomenologi sering didapatkan pada beberapa konflik dan fenomena yang ada pada lingkungan sekitar, baik di Indonesia atau pun di negara selain Indonesia. Salah satu di antara fenomena yang terjadi di dunia adalah fenomena mengenai senjata kimia yang terjadi di wilayah Timur Tengah, tepatnya di Ghouta Timur. Fenomena yang terjadi di Ghouta Timur merupakan fenomena yang akhirakhir ini menjadi sebuah topik pembicaraan di kalangan media, baik dari media Barat atau pun media Indonesia. Kedua media tersebut tak hentinya membahas mengenai konflik di Ghouta Timur.

Ghouta Timur merupakan suatu wilayah yang terletak di bawah komando Bashar al-Assad dan berjarak 10 kilometer sebelah Timur dari ibu kota Damaskus, Suriah. Secara mayoritas kependudukan yang ada di sana adalah penduduk sipil, bahkan sebagian besar merupakan anak-anak. Daerah tersebut menjadi pijakan terakhir para oposisi yang ada di Negara Suriah. Ketika kekuatan oposisi tersebut mulai surut, pasukan rezim Suriah atas perintah dari komandan Bashar al-Assad memulai rencana untuk menyelesaikan sekaligus membumihanguskan para oposisi tersebut. Dengan berakhirnya aliansi Bashar al-Assad berdampak terhadap selesainya sebuah konflik yang ada di Suriah. Akan tetapi, yang disayangkan di sini adalah penyelesaian konflik tersebut dengan cara genjatan senjata kimia dan beralihlah sasarannya, yaitu jatuh pada penduduk sipil, terutama pada kalangan anak-anak.

Berdasarkan pemaparan di atas, peneliti ingin mengungkap mengenai fenomena konflik senjata kimia yang berada di Ghouta Timur. Adapun rumusan masalah yang akan diteliti, yaitu: 1) Bagaimanakah konflik senjata kimia yang sebenarnya terjadi di Ghouta Timur; 2) Bagaimanakah dampak dari adanya konflik pendayagunaan senjata kimia di Ghouta Timur; 3) Bagaimanakah pandangan Media Indonesia terkait konflik senjata kimia di Ghouta Timur.

Sejalan dengan rumusan masalah yang sudah di paparkan di atas, maka tujuan dari penelitian ini adalah: 1) Untuk mengetahui konflik senjata kimia yang sebenarnya terjadi di Ghouta Timur; 2) Untuk mengetahui dampak terjadinya konflik pendayagunaan senjata kimia di Ghouta Timur, Suriah; dan 3) Untuk mengetahui pandangan media Indonesia terkait konflik senjata kimia di Ghouta Timur.

Penelitian ini memiliki manfaat secara teoritis. Adapun manfaat penelitian secara teoritis adalah sebagai berikut: 1) Sebagai kontribusi dalam 
memperdalam Kajian megenai Timur Tengah, terutama dalam konflik senjata kimia di Ghouta Timur, Suriah berdasarkan perspektif Edmund Husserl; 2) Sebagai referensi untuk memperdalam Kajian Timur Tengah dalam konflik senjata kimia di Ghouta Timur, Suriah berdasarkan perspektif Edmund Husserl.

\section{Hakikat Fenomenologi}

Istilah fenomenologi bersumber dari Bahasa Yunani phainomai yang berarti "menampak". Phenomenon merujuk pada "yang menampak". Fenomena merupakan sebuah fakta yang berlandaskan serta masuk ke dalam pemahaman manusia atau bisa dikatakan masuk akal [4].

Menurut The Oxford English Dictionary, fenomenologi merupakan a) the science of phenomena as distinct from being (ontology), dan b) division of any science which describes and claasifies its phenomena. Jadi, fenomenologi merupakan ilmu perihal peristiwa yang dibedakan dari sesuatu yang sudah terjadi, atau disiplin ilmu yang menjelaskan serta mengelompokkan suatu kejadian, atau studi tentang sebuah kejadian [4].

Orleans menyatakan bahwa fenomenologi merupakan suatu perangkat untuk mendalami lebih dalam mengenai keterkaitan antara kesadaran suatu individu dan kehidupan sosialnya. Fenomenologi berusaha menjelaskan bagaimana situasi sosial, aksi sosial, dan masyarakat dipandang sebagai hasil kesadaran manusia. Fenomenologi beranggapan bahwa masyarakat merupakan sebuah produk yang dibuat oleh manusia [2].

Tujuan paling mendasar dari fenomenologi adalah memahami perihal bagaimana suatu kejadian yang dialami dalam sebuah kesadaran, pikiran, dan dalam tindakan, seperti bagaimana fenomena tersebut memiliki sebuah nilai atau sanggup diterima secara elok [4].

\section{Konsep Fenomenologi Edmund Husserl}

Husserl merupakan seorang pencetus atau tokoh utama dari aliran filsafat fenomenologi. Fenomena menurut Husserl berbeda dengan makna fenomena menurut yang dijelaskan Immanuel Kant. Jika Kant mengatakan bahwa subjek hanya mengenal fenomena yang berarti tidak mencakup noumena, maka bagi Husserl fenomena mencakup apa yang dimaksud perihal noumena [4].

Filsafat fenomenologi Husserl merupakan filsafat yang tidak melibatkan perihal sangkaan atau perkiraan, karena hanya sanggup diidentifikasi melalui sebuah metode "reduksi". Metode reduksi akan berusaha mendalami sebuah karakter dasar kesadaran yang berupa niat atau keinginan. Pada saat seseorang mulai merefleksikan dunia yang telah tereduksi oleh dirinya, maka seseorang akan langsung menemukan bahwa dunia tidak menerapkan sifat pribadi namun dunia makna dan nilai yang telah diciptakan secara intersubjektivitas. Intersubjektivitas akan ada secara murni dalam suatu ego yang menjadi refleksi dan secara luas akan terbentuk dari sumber internasionalitas.

Husserl mengemukakan bahwa ilmu positif butuh sebuah pendamping berupa pendekatan filsafat fenomenologis. Pandangan Husserl dimulai dengan sebuah ajakan untuk kembali terhadap suatu sumber atau kembali kepada realitas yang sesungguhnya. Untuk itu, diperlukan berbagai tahapan metodis yang disebut "reduksi". Melalui reduksi, akan menunda sebuah penyimpulan sesuatu dari setiap prasangka terhadap suatu realitas. Tahapan-tahapan metodis yang dimaksud adalah reduksi eidetis, reduksi fenomenologi, dan reduksi transendental [2].

Tahapan pertama adalah reduksi yang disebut dengan reduksi fenomenologi. Reduksi fenomenologi merupakan tahap penyucian terhadap fenomena yang perlu dilewati oleh seorang peneliti. Reduksi fenomenologi mencakup semua pengalaman dalam bentuk kesadaran yang perlu dipilah, disaring atau didiamkan sementara. Ketika sebuah pengamatan berlangsung, peneliti perlu memahami mengenai "Ada apa di balik sebuah fenomena yang terlihat secara kasatmata itu?' bahkan perlu merunut "Apa yang dialami pelaku pada alam kesadaran?". Maksudnya adalah bahwa seorang peneliti perlu berusaha mendapatkan sebuah "inti" dari sebuah kejadian atau gejala sesungguhnya dari fenomena yang telah terjadi. Menurut Collins perihal yang dimaksudkan merupakan sebuah tahap dari penyaringan sementara dalam rangka memperoleh inti sebuah kejadian yang perlu dilakukan oleh seorang yang menyebut dirinya sebagai peneliti, maka ketika peneliti masuk ke dalam ranah lapangan, seorang peneliti mesti melepaskan diri dari segala karakter yang ada dalam dirinya seperti sebuah jabatan, agama, adat istiadat, ras, suku, dan pandangan ilmu pengetahuan yang dimiliki peneliti.

Tahapan kedua adalah reduksi yang disebut dengan reduksi eidetis. Reduksi eidetis memiliki tujuan untuk mendapatkan intisari dari inti yang sudah tercipta. Dalam mencapai beragam hal yang telah 
disebutkan peneliti mengambil rangkaian tahap yang dianjurkan oleh Bertens, yaitu: Pertama, peneliti akan selalu berusaha mengejawantahkan dalam bentuk imajinatif mengenai persoalan sosial yang hidup, maksudnya yaitu mengejawantahkan seakan-akan "Kegiatan penurunan Kades sedang dilaksanakan" (merupakan sebuah perumpamaan protes masyarakat kepada Kades). Dan kedua, berusaha mengidentifikasi dan mengklasifikasi perihal ragam data yang bersifat tetap atau tidak menunjukkan perubahan dalam berbagai ragam kondisi dan situasi. Melalui cara yang ditempuh ini, diharapkan sanggup memudahkan seorang peneliti secara langsung membuat sebuah pengelompokan dan identifikasi dalam memperolah data yang ada di lapangan. Pada tahap ini pencatatan data dan informasi dengan menggunakan catatan lapangan, dilakukan sesegera mungkin setelah tanya jawab naturalistik sedang berlangsung. Proses dari pengumpulan data dicukupkan ketika sudah dianggap "bosan" yaitu setelah tidak ada ragam jawaban baru lagi yang muncul dari lapangan.

Tahapan ketiga adalah reduksi yang disebut dengan reduksi transendental. Reduksi transendental akan berusaha membedakan inti yang masih memiliki sifat empiris menjadi inti murni. Hal yang empiris dipilah, sehingga hanya meninggalkan kesadaran aktivitas itu sendiri berupa kesadaran murni. Setelah itu akan mencapai fase kesadaran murni tempat untuk membuat atau merangkai sebuah objek yang dijadikan sebagai sasaran. Dalam fase ini subjek menjalani dirinya sendiri dan kebenaran yang dicapai merupakan kecocokan antara apa yang dilihat, dipikir dan dialami dengan makna yang ditemukan oleh seorang peneliti. Hal ini yang disebut sebuah esensi.

Reduksi transendental yang dimaksudkan sebenarnya ditijukan untuk mendapatkan esensi secara murni. Untuk mendapatkan kejernihan atau kemurnian sebuah data, peneliti perlu melewati tahap klarifikasi data terhadap data yang sudah menjadi satu kesatuan. Tahap dari klarifikasi yang dimaksudkan dilakukan dengan menggunakan berbagai sumber dan teknik yang disebut dengan istilah investigator triangulation [2].

Ketika melewati tahap reduksi transendental, Husserl menemukan sebuah esensi kesadaran yang disebut intensionalitas. Setiap kegiatan intensional merupakan kegiatan menyadari suatu kejadian. Pengertian dari kesadaran selalu dikaitkan dengan kesesuaian dengan sasaran yang dituju, yaitu sebuah sasaran yang disadari. Dalam redusi kepentingan mendasar terletak pada reduksi isi, bukan terletak pada persoalan menempatkan penampakan fenomena dalam sebuah tanda kurung, melainkan pada tahap bagaimana seseorang memberikan interpretasi terhadap sasaran selanjutnya [4].

Pengamatan Husserl mengenai sebuah struktur intensionalitas kesadaran, menyimpulkan bahwa setidaknya terdapat empat kegiatan yang inheren dalam sebuah kesadaran, yaitu 1) Konstitusi 2) Korelasi, 3) Identifikasi, dan 4) Objektifikasi [4].

\section{Kelebihan dan Kekurangan Fenomenologi}

Sebagai sebuah teori, fenomenologi disamping memiliki sebuah kelebihan juga tidak lepas dari sebuah kekurangan atau kelemahan. Kelebihan fenomenologi dalam memahami sebuah perlawanan masyarakat dibandingkan pendekatan lain, antara lain adalah sebagai berikut: 1) Sanggup mendalami mengenai perlawanan dengan lebih detail, 2) Sanggup lebih detail dalam menyimpulkan suatu perkara. Penyimpulan akan dilakukan setelah melalui proses "reduksi". Melalui proses reduksi, ada upaya untuk menunda sebuah proses penyimpulan sesuatu dari setiap prasangka terhadap realitas, 3) Sanggup menggali dunia subjektif yang terus berkembang, unik, beragam, aktif, dan khas secara interpretatif, 4) Sanggup menyajikan beragam makna yang berkembang di luar makna umum, 5) Sanggup membangun percakapan atau komunikasi antara individu dengan lingkungan sehingga mecapai keseimbangan dalam mendalami fenomena sosial, 6) Sanggup mendalami kegiatan manusia sebagai sesuatu yang bermakna bagi peran dalam masyarakat [2].

Craib menuturkan bahwa metodologi yang ditawarkan oleh Schutz hanya akan menangkap makna tindakan orang awam sebagaimana orang awam sendiri memahami makna tersebut. Jadi, gambaran yang diberikan Schutz mengenai fenomena hanya bersifat dangkal sehingga tidak sanggup menyelami makna lebih dalam [2].

Selain yang disebutkan di atas mengenai kelemahan dari pendayagunaan analisis fenomenologi, kelemahan dari analisis ini yaitu terlalu memuja seorang individu dalam proses pengambilan data, pemakaian, pemahaman subjektif, sehingga hasil analisisnya bukan sebagai kajian yang bersifat menyeluruh, melainkan nampak seperti hanya sanggup mencakup beberapa hal saja [2]. 


\section{Pendayagunaan Teori dalam Fenomenologi}

Penelitian mengenai fenomenologi sesungguhnya merupakan anggapan yang didapatkan sebelum mengetahui kejadian sebenarnya, sehingga tidak diawali dan didasari oleh teori tertentu. Penelitian fenomenologi merupakan penelitian yang berangkat dari pandangan filsafat, mengenai "apa" yang dicermati, dan bagaimana cara mencermatinya. Adapun hipotesis yang mendasar yang digunakan dalam penelitian fenomenologi adalah sebagai berikut [4]:

a. Peristiwa akan bermakna bagi mereka yang mengalami secara langsung.

b. Akan menjadi penelitian yang objektif ketika diperoleh melalui pengalaman yang dialami.

c. Pengalaman manusia terdapat dalam sebuah struktur pengalaman itu sendiri. Tidak dikonstruksi oleh seorang peneliti.

\section{METODE}

Penelitian ini tergolong sebagai penelitian kualitatif deskriptif. Data yang digunakan bersumber dari beberapa media yang ada di Indonesia yang memberitakan mengenai sebuah konflik senjata kimia di Ghouta Timur. Adapun tahap dari penelitian ini adalah seperti berikut:

1. Mengaji berita dari media Indonesia terpercaya seperti CNN Indonesia terkait konflik senjata kimia di Ghouta Timur dengan saksama untuk mencari data.

2. Memilah sekumpulan data yang berhubungan dengan kajian fenomenologi dari Edmund Husserl kemudian mengesampingkan data yang tidak berhubungan dengan kajian fenomenologi.

3. Mengelompokkan sekumpulan data yang masih memiliki keterkaitan atau hubungan terhadap kajian fenomenologi Edmund Husserl.

4. Melakukan analisis melalui pembacaan cermat terhadap ragam dari berita di media terkait konflik senjata kimia di Ghouta Timur dan mengkajinya dengan teliti.

5. Melakukan penarikan sebuah kesimpulan.

\section{HASIL DAN PEMBAHASAN}

Konflik atau fenomena sudah tak asing lagi dalam suatu lingkup kehidupan. Untuk mengetahui suatu fenomena tersebut digolongkan benar atau tidaknya, Edmund Husserl memperkenalkan istilah reduksi. Reduksi merupakan suatu metode untuk mengetahui fenomena secara kasatmata tanpa ada sebuah prasangka. Adapun data-data yang telah di dapat dalam beberapa surat kabar online atau elektronik, yaitu:

Terhitung sudah lebih dari sewindu yang lalu konflik di Suriah tak kunjung selesai. Konflik tersebut bermula dari munculnya sebuah rasa ketidakpuasan oleh rakyat yang kemudian melakukan penentangan terhadap pemerintah. Pada saat itu pemerintahan berada di bawah masa pemerintahan Bashar al-Assad [5]. Jika dilihat konflik yang terjadi di Suriah setiap hari akan semakin parah dikarenakan timbulnya pertikaian antara kedua pihak dengan menggunakan senjata kimia. Dari kelompok PBB sudah menganggap bahwa pendayagunaan senjata kimia dalam peperangan merupakan "kejahatan luar biasa". Pemberontakan tersebut membuat Assad beserta seluruh tentara yang ada di pemerintah berusaha untuk melawan dan membumihanguskan para pemberontak yang ada di sana [6].

Sebelum muncul sebuah konflik di Suriah tahun 2018, sudah muncul beberapa negara yang menggunakan senjata kimia dalam sebuah perang. Senjata kimia merupakan salah satu dari kategori senjata pemusnah massal yang berbahaya dan berdampak buruk hingga sanggup mematikan. Dua senjata pemusnah massal yang dimaksudkan adalah senjata nuklir dan senjata biologi. Salah satu daerah yang menjadi hal yang dipersangkutkan adalah Ghouta Timur [7].

Ghouta Timur merupakan salah satu daerah dengan jarak 10 kilometer dari ibu kota Damaskus. Dimana daerah tersebut terdapat beberapa kelompok yang mengaku sebagai kumpulan mujahidin. Sebagian dari mereka bersekongkol dengan al-Qaeda, dan sebagian yang lain berafiliasi dengan Ikhwanul Muslimin. PBB sudah mengakui bahwa yang bersekongkol dengan alQaeda merupakan seorang teroris [8]. Sedangkan menurut media dan politisi barat menilai bahwa yang bersekongkol dengan Ikhwanul Muslimin, merupakan pihak seroang pemberontak moderat. Di antara kelompok yang bersekongkol dengan alQaeda adalah Jaish al-Islam, Faylaq ar-Rahman, Hay'at Tahrir al Sham, Harakat Nour al Din al Zenki, dan Harakat Ahrar al Sham al-Islamiyyah.

Dari kelompok pemberontak yang paling kuat adalah Jaish al-Islam. Jaish al-Islam merupakan sebuah kelompok yang berada dalam dukungan Arab Saudi dengan maksud untuk menggantikan 
pemerintah Suriah menjadi Negara Islam. Sedangkan kelompok terbesar kedua setelah Jaish al-Islam adalah Faylaq ar-Rahman. Kelompok tersebut bersekutu dengan Hay'at Tahrir al Sham. Selain Hay'at Tahrir al Sham, Harakat Nour al Din al Zenki dan Harakat Ahrar al Sham al-Islamiyyah juga memiliki kehadiran kecil di Ghouta Timur [9].

Hadirnya para pemberontak mengakibatkan Bashar al-Assad beserta para tentaranya bergerak melawan para pemberontak tersebut. Tujuan dari pergerakan yang dilakukan Bashar al-Assad beserta para tentaranya adalah untuk membersihkan dan menuntaskan para pemberontak yang ada di Ghouta Timur. Ketika koalisi dari pihak para pemberontak mulai surut, barulah Assad merencanakan upaya tersebut. Dengan begitu, tentara Suriah akan dengan mudah dalam menyelesaikan perberontakan tersebut. Dengan usainya pemberantasan tersebut, maka usai pula konflik yang ada di Suriah.

Para pemberontak yang mengaku sebagai mujahidin menculik penduduk sipil karena direncanakan digunakan sebagai perisai agar kala tentara Suriah menyerang pemberontak tersebut yang terkena lebih dahulu adalah penduduk sipil, bukan mereka. Ada sebagian warga sipil yang dikurung dalam kandang dan bahkan diarak mengelilingi kota bagaikan seekor binatang. Hal tersebut merupakan persoalan yang sangat disayangkan dalam pemberontakan tersebut. Selain itu, dalam pemberontakan kali ini juga tak terlepas dari persoalan pendayagunaan senjata kimia yang sangat membahayakan dan berdampak buruk bagi manusia maupun lingkungan [10].

Hampir seluruh rakyat di Ghouta Timur yang menjadi korban adalah anak-anak yang tak bersalah bahkan tak tahu menahu mengenai persoalan peperangan tersebut. Dapat dipastikan bahwa yang menjadi korban mencapai ratusan bahkan bisa dikatagorikan ribuan orang meninggal dunia karena kekurangan oksigen. Semakin hari korban silih bertambah tanpa henti. Tidak sedikit penduduk yang masih hidup diliputi oleh ketakutan dan kekhawatiran akan hilangnya nyawanya sendiri atau pun keluarga dan teman-temanya yang masih hidup.

Pemberitaan mengenai fenomena yang berlangsung hingga lebih sewindu sangat memperihatinkan. Pada umumnya media cetak dan elektronik atau online lebih mengandalkan sumber dari media "Deutsche Welle" yang berat sebelah dalam memberitakan. Ketidakseimbangan pemberitaan tersebut yang akan mengakibatkan adanya salah persepsi. Sehingga para pembaca lebih cenderung menyalahkan rezim tentara Assad.

Terdapat beberapa media Barat yang memberitakan tentang konflik di Ghouta Timur. Salah satunya adalah "White Helmet". White Helmet merupakan sumber propaganda dan sebenarnya dapat digolongkan sebagai anggota kelompok teroris yang mengenakan pakaian relawan. Dr. Marcus Papadopoulos menuturkan bahwa White Helmet selalu menjadi pijakan informasi mengenai konflik yang terjadi di Suriah. Media Barat sendiri tidak memperdulikan kearoganan dan kekejian yang dilakukan oleh para pemberontak dan lebih memilih untuk menyalahkan kekerasan yang dilakukan oleh rezim Suriah [11].

Sebagian media yang ada di Indonesia memperoleh sumber berita tidak sepenuhnya murni diperoleh dari sumber secara langsung pada titik fenomena, tetapi mengambil dari berita terjemahan atau menulis ulang berita dari media Barat. Namun ada beberapa pengamat Timur Tengah, yaitu Dina Y Sulaeman dan Tia Mariatul Kibtiyah, yang mengangap bahwa pemberontakan yang terjadi antara pihak tentara Assad dan pihak para pemberontak dilakukan melalui cara pendayagunaan senjata kimia yang dianggap sangat membahayakan untuk manusia, hewan, atau pun lingkungan. Permasalahan yang paling disayangkan adalah bahwa selain warga sipil, kebanyakan masyarakat yang hidup di Ghouta Timur adalah anak-anak. Hal tersebut merupakan persoalan yang selama ini tak ditampilkan oleh media Barat terkait konflik yang terjadi di Ghouta Timur [12].

Menurut kabar terakhir disebutkan bahwa konflik di Ghouta Timur telah usai. Disebutkan pula bahwa tidak ada yang perlu dirisaukan atau dikhawatirkan akan keberlanjutan dari konflik di Ghouta Timur. Penuturan tersebut diambil dari ungkapan dubes Ghouta dalam tulisan Suastha yang dipublikasikan melalui CNN [13].

Pemberitaan yang benar atas konflik tersebut sebenarnya untuk kepentingan masyarakat Indonesia dalam memandang suatu organisasi. Hal itu dikarenakan para orang yang mengaggap dirinya seorang mujahidin atau bisa disebut pemberontak sudah bersekongkol dengan beberapa organisasi masyarakat transnasional yang memiliki 
cabang di Indonesia. Ormas yang dimaksudkan adalah al-Qaida, Hizbut Tahrir, Ikhwanul Muslimin, dan lain sebagainya.

\section{KESIMPULAN}

Teori Fenomenologi menjadi sebuah metode untuk mengetahui konflik atau fenomena yang sesungguhnya berlangsung di berbagai daerah, khususnya daerah Ghouta Timur. Dalam konflik yang terjadi di Ghouta Timur sangat disesalkan oleh banyak pihak dikarenakan diselesaikan dengan menggunakan salah satu senjata pemusnah massal, yaitu senjata kimia. Sebagaimana kita ketahui bahwasanya senjata kimia merupakan sebuah piranti yang sangat berbahaya, baik untuk organ tubuh, lingkungan alam dan lain-lain. Akan tetapi, cara tersebut merupakan pilihan yang telah dilakukan oleh tentara Suriah atas perintah Bashar al-Assad untuk membersihkan, memberantas, atau membumihanguskan para oposisi atau bisa disebut sebagai musuh yang ada disana. Banyak korban yang berjatuhan dalam konflik tersebut, terutama anak-anak.

Disebutkan bahwa pada 2021 daerah Ghouta Timur sudah aman dari segala persoalan yang ditakutkan. Jadi, muncul himbauan yang dimuat oleh CNN untuk tidak perlu risau lagi perihal konflik yang terjadi di Ghouta Timur.

Terdapat perselisihan pandangan dalam pemberitaan tentang konflik tersebut. Media Barat lebih menaruh kesalahan atas kekejaman dari pihak rezim Assad, sedangkan media Indonesia lebih cenderung sebaliknya. Perselisihan inilah yang akan mengakibatkan munculnya persepsi yang berbeda.

\section{REFERENSI}

[1] A. Samekto, "Larangan Penggunaan Senjata Kimia dalam Peperangan," Jurnal Hukum dan Pembangunan, vol. XIX, no. 6, p. 581, 2017.

[2] I. B. Wirawan, Teori-teori Sosial dalam Tiga Paradigma (Fakta Sosial, Definisi Sosial \& Perilaku Sosial), Jakarta: Kencana, 2012.

[3] S. Haryanto, Spektrum Teori Sosial: dari Klasik hingga Postmodern, Yogyakarta: ArRuzz Media, 2012.

[4] E. Kuswarno, Metodologi Penelitian Komunikasi Fenomenologi Konsepsi,
Pedoman, dan Contoh Penelitiannya, Semarang: Widya Padjajaran, 2009.

[5] L. Rodgers, D. Gritten, J. Offer, dan P. Asare, "Syria: The story of the conflict" BBC, 11 Maret 2016 [Online]. Available: https://www.bbc.com/news/world-middleeast-26116868. [Diakses 17 Januari 2021].

[6] A. Pujayanti, "Senjata Kimia dan Konflik Suriah," Info Singkat Hubungan Internasional, vol. VIII, no. 21, pp. 5-8, 2016.

[7] N. R. Michico, "Jejak Penggunaan Senjata Kimia dalam Perang," iNews.id, 28 Februari 2018. [Online]. Available: https://www.inews.id/news/internasional/jeja k-penggunaan-senjata-kimia-dalam-perang. [Diakses 17 Januari 2021].

[8] D. Sulaeman, "Siapa yang Ada di East Ghouta," Dina Sulaeman WordPress, 27 Februari 2018. [Online]. Available: https://dinasulaeman.wordpress.com/2018/02 /27/siapa-yang-ada-di-east-ghouta/. [Diakses 17 Januari 2021].

[9] D. Sulaeman, "Mengapa Suriah Penting Dipahami Orang Indonesia," Dina Sulaeman WordPress, 11 Maret 2018. [Online]. Available:https://dinasulaeman.wordpress.co m/2018/03/11/mengapa-suriah-pentingdipahami-orang-indonesia/. [Diakses 17 Januari 2021]

[10] R. B. News, "Sepuluh Pertanyaan untuk Memahami Konflik Suriah," BBC News Indonesia, 15 Maret 2018. [Online]. Available:https://www.bbc.com/indonesia/du nia-43403254. [Diakses 17 Januari 2021].

[11] D. Sulaeman, "Analisis Kritis terhadap Media (Kasus East Ghouta)," Dina Sulaeman WordPress, 27 Februari 2018. [Online]. Available:https://dinasulaeman.wordpress.co m/2018/02/27/analisis-kritis-terhadap-mediakasus-east-ghouta/. [Diakses 17 Januari 2021].

[12] T. M. Kibtiah, "Suriah Kembali Berdarah, Dukungan AS \& Arab Saudi Menurun - via Phone, Tia Mariatul Kibtiah," CNN Indonesia YouTube Channel, 27 Februari 2018. [Online]. Available: https://www.youtube.com/watch?v=h8qYXJ kJK7w . [Diakses 17 Januari 2021].

[13] R. D. Suastha, "Dubes Suriah: Ghouta Timur Sudah Aman," CNN Indonesia, 3 Maret 2018. [Online]. Available: 
https://www.cnnindonesia.com/internasional/ 20180323144649-126-285367/dubes-suriah

ghouta-timur-sudah-aman . [Diakses 17 Januari 2021]. 